\title{
Molecular detection and characterization of begomoviruses associated with cucurbitaceae vegetables in Sri Lanka
}

\author{
W.M.E.K. Bandaranayake ${ }^{1}$, W.A.R.T. Wickramarachchi1 ${ }^{*}$, H.A.M. Wickramasinghe ${ }^{2}$, R.G.A.S. \\ Rajapakshe $^{1}$ and D.M.K.K. Dissanayake ${ }^{1}$ \\ ${ }^{1}$ Horticultural Crop Research and Development Institute, Gannoruwa, Peradeniya \\ ${ }^{2}$ Department of Agricultural Biology, Faculty of Agriculture, University of Peradeniya, P.O. Box 55, Peradeniya.
}

\begin{abstract}
The family cucurbitaceae includes certain popular fruits and vegetables grown in various tropical and subtropical areas in the world. However, viral diseases are a major constraint causing heavy economical losses in cucurbits. Although a number of viral diseases have been reported in cucurbits in Sri Lanka, there are no reports of begomoviruses. A whitefly transmitted viral disease with severe leaf curl symptoms has been reported in bitter gourd from Sri Lanka (Momordica charantia), which was suspected to be due to a begomovirus. A PCR assay has been conducted using universal primers (Deng 540 and Deng 541) specific for begomoviruses to detect the viruses associated with various cucurbits showing viral symptoms. The begomovirus associated with bitter gourd was characterized by nucleotide sequence analysis. Infection by begomoviruses in bitter gourd, ridge gourd (Luffa acutangula), pumpkin (Cucurbita maxima), cucumber (Cucumis sativus) and snake gourd (Trichosanthes cucumerina) plants, which showed symptoms of upward leaf curl, leaf mosaic, shortening internodes, mottling, stunting, rosetting, puckering, reduced leaf lamina, fruit malformation and flatterning of tender stems were confirmed by consistent amplification of core coat protein $\mathrm{CP}$ gene fragment of $520 \mathrm{bp}$. No amplification was observed with healthy cucurbit samples. The sequence comparison and phylogenetic analysis of the coat protein gene of begomovirus in bitter gourd (Begomo-Bitter Gourd-Sri Lanka Virus) showed $97 \%$ nucleotide identity and a close genetic relationship with the Tomato leaf curl New Delhi virus in bitter gourd found in Pakistan (ToLCNDV-BG).
\end{abstract}

Keywords: Begomovirus, cucurbits, molecularcharacterization, PCR.

\section{INTRODUCTION}

The cucurbitaceae is an important plant family comprising many vegetables and fruits such as cucumber, squash, pumpkin, melons and gourds. They are grown in various tropical and subtropical regions, arid deserts and temperate locations in the world $(\mathrm{Ng}, 1993)$. Cucurbits commonly cultivated in Sri Lanka include cucumber (Cucumis sativus), bitter gourd (Momordica charantia), snake gourd (Trichosanthes cucumerina), ridge gourd (Luffa acutangula), pumpkin (Cucurbita maxima), ash pumpkin (Benincasa hispida), water melon (Colocynthis citrullus) and "kekiri" (Cucumis pubescens) (Ariyaratne et al., 2005).

There are many pests and diseases that significantly affect the yield and fruit quality of cucurbits. Among these diseases, viral diseases are more important as they cause heavy economic losses and are difficult to diagnose accurately leaving limited options for management. Approximately more than 35 viruses has been isolated from the family cucurbitaceae (Ozaslan et al., 2006). Early diagnosis of viral diseases along with accurate identification of their causal agents and mode of transmission is essential for formulating and establishing management measures (Ozaslan et al., 2006). The symptoms of virus infected plants may resemble those due to fungal or bacterial diseases and environmental stress. Hence, diagnosis on the basis of symptoms alone is inaccurate. Accurate identification of viruses require reliable methodologies (Kushwaha et al., 2010) and polymerase chain reaction (PCR) using specific primers has proved to be a rapid, accurate and efficient method of detecting viruses. Sequencing of PCR fragments have contributed to the classification and phylogeny of viruses (Rojas et al., 1993; Deng et al., 1994).

Cucumber Mosaic Virus (CMV), Papaya Ring Spot 
Virus (PRSV), Zucchini Yellow Mosaic Virus (ZYMV), Cucumber Green Mottle Mosaic Virus (CGMMV), Tobacco Ring Spot Virus (TRSV) and Tomato Ring Spot Virus (ToRSV) have been reported on cucurbits in Sri Lanka (Anon., 2008). A severe leaf curl condition along with leaf mosaic, stunting and fruit malformation with unknown etiology has been reported in bitter gourds in Sri Lanka. The virus or viruses associated with these diseased plants were transmitted by whiteflies (Bemisia tabaci). It was not transmitted by seeds nor by mechanical transmission (Weerasinghe, 2010). Similar symptoms were also found to be associated with a number of cucurbits including ridge gourd, pumpkin, cucumber and snake gourd.

Begomoviruses belonging to family Geminiviridae, are the most numerous of the Bemisia tabaci transmitted viruses and has caused crop yield losses between 20 - $100 \%$ (Brown \& Bird, 1992). They are characterized by their unique paired icosahedral capsids (Lazarowitz $\&$ Shepherd, 1992), and the genome consists of single stranded closed circular DNA. Many begomoviruses have a bipartite genome with DNA-A and DNA-B and some viruses have a monopartite genome with only DNA-A (Pooma et al., 1996). The first identified cucurbit infecting begomovirus was Squash leaf curl virus, which was associated with leaf curl and stunted growth of squash in Imperial Valley in California (Hagen et al., 2008).

Based on the symptoms and the transmission by the whitefly, a begomovirus infection was suspected and a PCR was carried out to detect the begomoviruses associated with different cucurbit vegetables. The begomovirus associated with bitter gourd was characterized by nucleotide sequencing and phylogenic analysis.

\section{METHODS AND MATERIALS}

\section{Sample collection}

Leaf samples from bitter gourd, ridge gourd, snake gourd, cucumber and pumpkin, which showed viral symptoms of leaf mosaic, upward leaf curling, shortening internodes, stunting, rosetting, puckering, reduced leaf lamina, mottling, fruit malformation and flattening of tender stem were collected from research fields in the Horticultural Crops Research and Development Institute in Gannoruwa, Makandura and Wanathawilluwa. Greenhouse grown healthy leaf samples, which were apparently free from viral symptom were also collected.

\section{Total DNA extraction}

Total DNA was extracted from infected and healthy plant samples using modified cetyltrimethylammonium bromide (CTAB) method (Lodhi et al., 1994). $150 \mathrm{mg}$ of leaf tissue was homogenized with $1.5 \mathrm{~mL}$ of preheated (to $65^{\circ} \mathrm{C}$ ) DNA extraction buffer $(0.1 \mathrm{M}$ Tris $\mathrm{HCl}$, $0.2 \mathrm{M}$ EDTA, $1.4 \mathrm{M} \mathrm{NaCl}, 2 \%$ CTAB, $1 \%$ PVP, ßmercaptoethanol). The homogenized material was transferred into a $1.5 \mathrm{~mL}$ eppendorf tube and incubated at $65^{\circ} \mathrm{C}$ for $30 \mathrm{~min}$. Then tube was the centrifuged at 2,000 rpm for $1 \mathrm{~min}$ and the supernatant was transferred to a new eppendorf tube. An equal volume of chloroform: isoamyl alcohol (24:1) was added, mixed by gentle inversion and centrifuged at $12,000 \mathrm{rpm}$ for $10 \mathrm{~min}$. The resulting supernatant was transferred to a fresh eppendorf tube and isopropanol was added. The tube was then inverted several times and incubated overnight at $-20{ }^{\circ} \mathrm{C}$. DNA was pelleted by centrifugation for $5 \mathrm{~min}$ at $12,000 \mathrm{rpm}$. The pellet was washed with $70 \%$ ethanol and dried at room temperature for 20 min until all traces of ethanol disappeared. Finally the pellet was dissolved in $100 \mu \mathrm{L}$ of $1 \mathrm{X}$ TE buffer and stored at $-20^{\circ} \mathrm{C}$.

\section{PCR detection of begomovirus}

A set of degenerate primers (Deng 540TGGACYTTRCAWGGBCCTTCACA and Deng 541-TAATATTACCKGWKGVCCSL) capable of amplifying part of the coat protein (CP) gene of DNA-A in begomovirus (Deng et al., 1994) was used to amplify virus DNA in the samples. $10 \mu \mathrm{L}$ of reaction mixture containing $5 \mu \mathrm{L}$ of master mixture (Taq.PCR Master mixture-Qiagen), $0.8 \mu \mathrm{L}$ of each primer (10 mM), $0.5 \mu \mathrm{L}$ of diluted (1:25) infected or healthy DNA and sterile water was added to make up the volume. Bean yellowing virus DNA sample was used as the positive sample, which was previously detected as a begomovirus (Wickramaarachchi et al., 2012). The PCR programme used was one cycle of initial denaturation at $94{ }^{\circ} \mathrm{C}$ for 4 min followed by 30 cycles of denaturation at $94^{\circ} \mathrm{C}$ for $1 \mathrm{~min}$, annealing at $61{ }^{\circ} \mathrm{C}$ for $1 \mathrm{~min}$, extension at $72{ }^{\circ} \mathrm{C}$ for $1.5 \mathrm{~min}$ and a final extension at $72{ }^{\circ} \mathrm{C}$ for $10 \mathrm{~min}$. The PCR products were visualized by $1.5 \%$ agarose gel electrophoresis for $1 \mathrm{~h}$ at $80 \mathrm{~V}$ (Figure 1).

\section{Sequencing and phylogenic analysis of Begomo-Bitter Gourd-Sri Lanka Virus}

The PCR product of an infected bitter gourd sample was named as Begomo-Bitter Gourd-Sri Lanka Virus (Begomo-Bitter Gourd-SL Virus). The 520 bp PCR product was cleaned using Wizard gel and PCR clean- 
up kit (promega) and sent to Gene Tech Pvt. Ltd., 54, Kitulwatte Road, Colombo 08, Sri Lanka for bidirectional sequencing. FASTA forms of the result sequences were edited and analyzed using basic local alignment search tool (BLAST) (Altschul et al., 1990) based on the close sequence identity and the length of the sequences.
The phylogenetic analysis was performed to find the relationship of Begomo-BitterGourd-SL Virus with other published geminiviruses using MEGA (molecular evolutionary genetic analysis) 4.0 software by neighbourjoining method (Tamura et al., 2007) at 1000 bootstrap value.

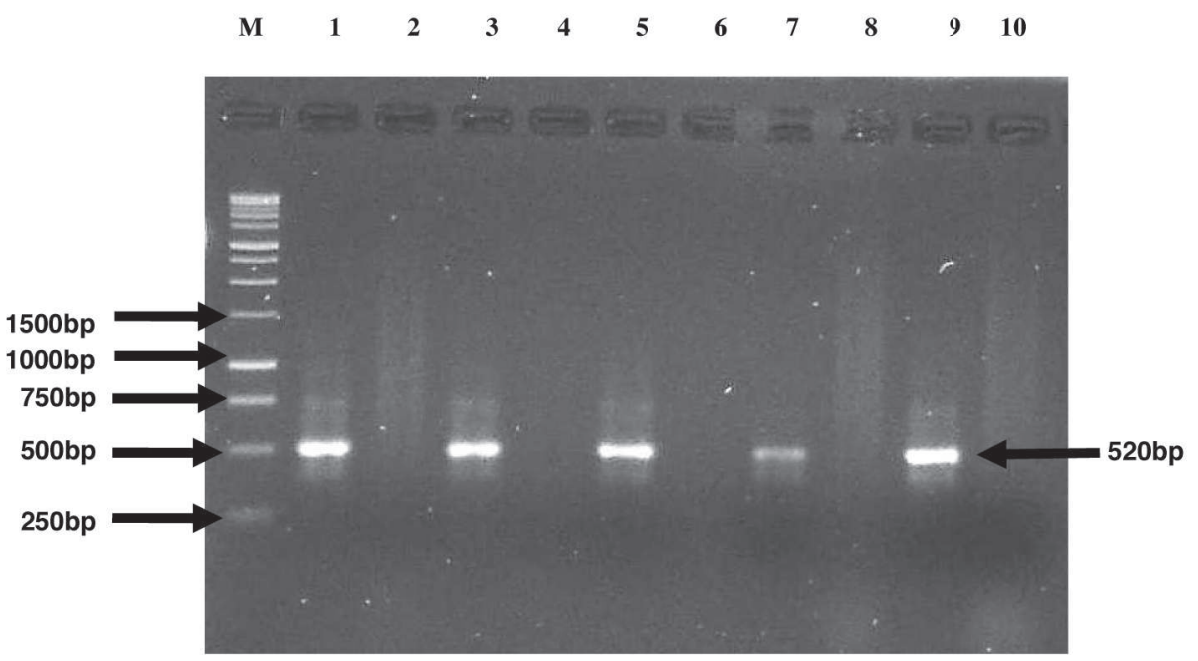

Figure 1: Molecular detection of begomovirus in cucurbit samples using degenerate primers.

Lane M - 1 kb DNA ladder (promega-G571A); Lane 1- infected bean sample (positive control); Lane 2 - healthy bean sample; Lane 3 - infected bitter gourd sample; Lane 4 - healthy bitter gourd sample; Lane 5 - infected ridge gourd sample; Lane 6 - healthy ridge gourd sample; Lane 7 - infected pumpkin sample; Lane 8 - healthy pumpkin sample; Lane 9 - infected snake gourd sample; Lane 10 - healthy snake gourd sample
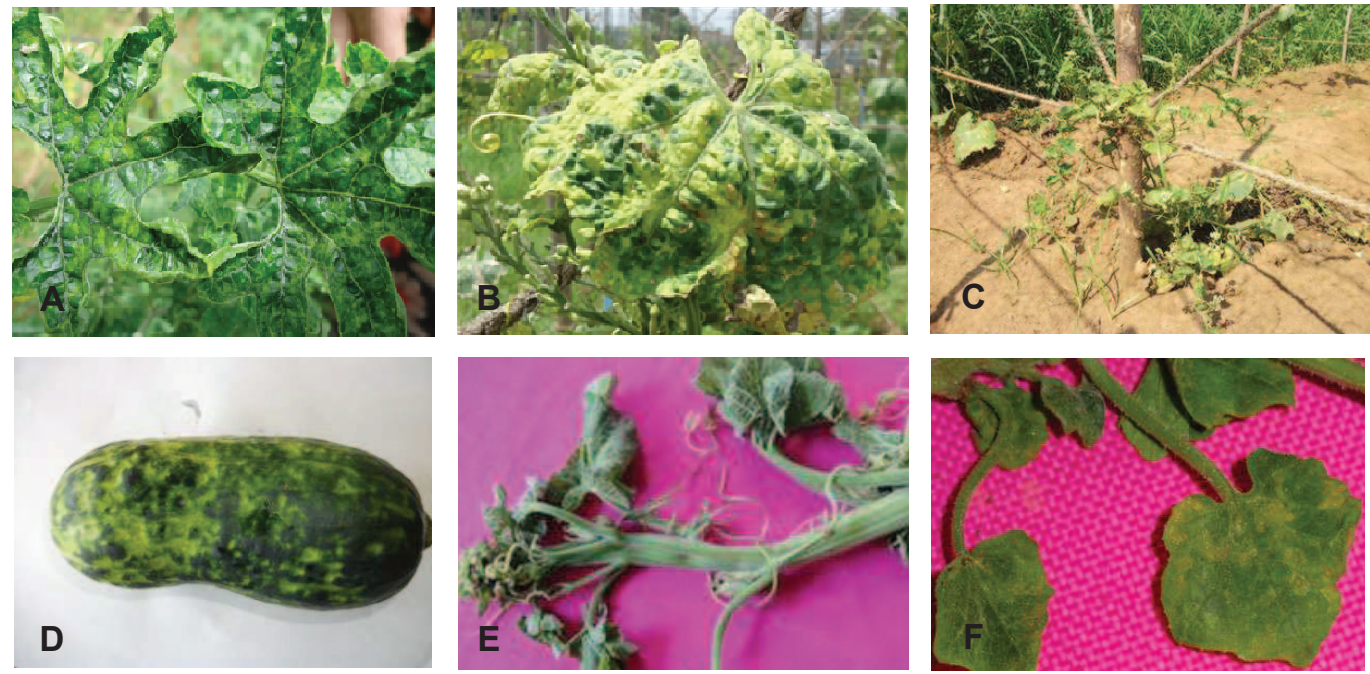

Figure 2: Different viral symptoms shown by cucurbit crops.

A-bitter gourd; B and C- ridge gourd; D and E-pumpkin; F-snake gourd 


\section{RESULTS}

\section{PCR detection of begomovirus}

PCR assay was carried out using a set of degenerate primers successfully amplified expected DNA fragments of $520 \mathrm{bp}$ (Figure 1) from infected bitter gourd, ridge gourd, snake gourd, cucumber and pumpkin DNA samples. Infected bitter gourd and ridge gourd plants showed leaf mosaic, upward leaf curling, shortening internodes, stunting, rosetting, puckering, reduced leaf lamina and fruit malformation (Figure 2-A,B and C). Pumpkin plants showed flattening of tender stems in addition to the above symptoms (Figure 2-E). Cucumber plants showed upward leaf curling, while snake gourd plants showed leaf mosaic and reduced leaf lamina without upward leaf curling (Figure 2-F).

Table 1: Maximum identities between partial CP coat protein gene sequence of begomovirus associated with bitter gourd in Sri Lanka and other closely related begomoviruses

\begin{tabular}{|c|c|c|c|}
\hline Description & Abbreviation & $\begin{array}{l}\text { Accession } \\
\text { number }\end{array}$ & $\begin{array}{l}\text { Max } \\
\text { ident }\end{array}$ \\
\hline Tomato leaf curl New Delhi virus - Bitter gourd DNA A & ToLCNDV-BG & AM747291 & $97 \%$ \\
\hline Tomato leaf curl New Delhi virus - (Pakistan: Solanum) & ToLCNDV-(Solanum: Pakistan) & DQ116885 & $97 \%$ \\
\hline Luffa begomovirus coat protein ( $\mathrm{AV} 1), \mathrm{AC} 3$ ( $\mathrm{AC} 3$ ), and $\mathrm{AC} 2(\mathrm{AC} 2)$ genes & $\mathrm{LBgV}$ & AY309957 & $97 \%$ \\
\hline Tomato leaf curl virus isolate Raebareli segment DNA-A & ToLCNDV-(Raebareli) & JX232220 & $96 \%$ \\
\hline Tomato leaf curl New Delhi virus - India (India:Hissar:Cotton:2005) & ToLCNDV-(Cotton: Hissar) & EF063145 & $96 \%$ \\
\hline Tomato leaf curl New Delhi virus - chili pepper clone PC2No10 segment A & ToLCNDV-(chili) & DQ116880 & $96 \%$ \\
\hline Tomato leaf curl New Delhi virus isolate SILIGURI & ToLCNDV-(SILIGURI) & HQ597032 & $96 \%$ \\
\hline Tomato leaf curl New Delhi virus-(Pumpkin: New Delhi) segment DNA-A & ToLCNDV-(Pumpkin: New Delhi) & AM286434 & $96 \%$ \\
\hline Tomato leaf curl New Delhi virus-(Multan: Luffa) V2 gene & ToLCNDV-(Luffa: Multan) & AM292302 & $96 \%$ \\
\hline Tomato leaf curl New Delhi virus isolate India:Delhi:Cucumis:2012 segment DNA-A & ToLCNDV- (Cucumis: Delhi) & KC545812 & $96 \%$ \\
\hline Tomato leaf curl New Delhi virus-India isolate Lucknow segment DNA-A & ToLCNDV-(Lucknow) & KC513822 & $96 \%$ \\
\hline Tomato leaf curl New Delhi virus-India (India/New Delhi/Chilli/2009) & ToLCNDV-(Chilli: New Delhi) & HM007113 & $96 \%$ \\
\hline Tomato leaf curl New Delhi virus-Mild coat protein & ToLCNDV-(Mild) & U15016 & $96 \%$ \\
\hline Tomato leaf curl New Delhi virus-Severe segment DNA A & ToLCNDV-(Severe) & HM159454 & $96 \%$ \\
\hline Tomato leaf curl New Delhi virus-India (India/Tumkur/Chilli/2008) & ToLCNDV-(Chilli: Tumkur) & HM007120 & $95 \%$ \\
\hline Tomato leaf curl New Delhi virus DNA-A complete genome, isolate Himachal & ToLCNDV-(Himachal) & AM850115 & $95 \%$ \\
\hline Tomato leaf curl New Delhi virus-(Potato) isolate Meerut segment DNA A & ToLCNDV-(Potato: Meerut) & EF043231 & $95 \%$ \\
\hline Squash leaf curl China virus-(Pumpkin:Varanasi) segment DNA-A & SqLCCNV-(Pumpkin: Varanasi) & EU573715 & $95 \%$ \\
\hline Squash leaf curl China virus-(Pumpkin :Coimbatore) segment DNA-A & SqLCCNV-(Pumpkin: Coimbatore) & AY184487 & $95 \%$ \\
\hline Tomato leaf curl New Delhi virus isolate Lahore segment DNAA, & ToLCNDV-(Lahore) & КС960492 & $95 \%$ \\
\hline Tomato leaf curl New Delhi virus-(Potato) isolate Happur segment DNA A & ToLCNDV-(Potato: Happur) & EF043230 & $95 \%$ \\
\hline Tomato leaf curl New Delhi virus-Papaya (India:New Delhi:Papaya:2005) segmentA & ToLCNDV-(Papaya :New Delhi) & DQ989325 & $95 \%$ \\
\hline Tomato leaf curl New Delhi virus-(Cucumber: Thailand) DNA & ToLCNDV-(Cucumber: Thailand) & AB330079 & $95 \%$ \\
\hline Tomato leaf curl New Delhi virus isolate parthenium segment DNA-A & ToLCNDV-(Parthenium) & KF002409. & $95 \%$ \\
\hline Tomato leaf curl New Delhi virus isolate eggplant segment DNA-A & ToLCNDV-(Eggplant) & HQ264185 & $95 \%$ \\
\hline Squash leaf curl China virus-(Pumpkin: Lucknow) segment DNA A & SqLCCNV-(Pumpkin: Lucknow) & DQ026296 & $95 \%$ \\
\hline Tomato leaf curl New Delhi virus isolate India: Ash gourd:2011 segment DNA-A & ToLCNDV-(Ash gourd) & JN208136 & $95 \%$ \\
\hline Tomato leaf curl New Delhi virus-(cucumber: Thailand:muskmelon) DNA & ToLCNDV-(Muskmelon: Thailand) & AB368448 & $95 \%$ \\
\hline Tomato leaf curl New Delhi virus-(cucumber: Thailand:bottle gourd) DNA & ToLCNDV-(Bottle gourd: Thailand) & AB368447. & $95 \%$ \\
\hline Tomato leaf curl New Delhi virus-(Pumpkin: New Delhi) segment DNA-A & ToLCNDV-(Pumpkin: New Delhi) & AM286433 & $95 \%$ \\
\hline Tomato leaf curl New Delhi virus (India:Bangalore:OY135:2005) segment DNA-A & ToLCNDV-(India: Bangalore) & GU112084 & $95 \%$ \\
\hline Tomato leaf curl New Delhi virus-(Potato) isolate Pot-Mer1-2002 segment DNA A & ToLCNDV-(Potato: Mer1) & AY286316 & $94 \%$ \\
\hline Bitter gourd yellow vein Virus-(Pakistan:Lahore:2004), segment A & BGYVV-(Lahore) & AM491590 & $93 \%$ \\
\hline Bhendi yellow vein Delhi virus (2004:New Delhi) isolate OY131 segment DNA-A & BYVDV- (New Delhi) & FJ515747 & $94 \%$ \\
\hline Squash leaf curl Philippines virus & SqLCV-(Philippine) & EU487041 & $90 \%$ \\
\hline Pumpkin yellow mosaic Malaysia virus isolate MP1 segment DNA A & PYMV-(Malaysia) & EF197941 & $89 \%$ \\
\hline Loofa yellow mosaic virus DNA-A & LYMV & AF509739 & $89 \%$ \\
\hline
\end{tabular}




\section{Sequencing and phylogenic analysis of Begomo- BitterGourd-SL Virus}

The nucleotide sequences of the Begomo-Bitter GourdSL Virus obtained from bidirectional sequencing of begomovirus CP gene was 497 bp in length. After editing the fragment, the remaining product was $422 \mathrm{bp}$ in length and it was used for further analysis.

Blast analysis of the Begomo-Bitter Gourd-SL Virus showed $97 \%$ nucleotide identity with the Tomato leaf curl New Delhi virus reported in bitter gourd (ToLCNDVBG) (AM747291), Tomato leaf curl New Delhi virus in Solanum [ToLCNDV-(Solanum: Pakistan) DQ116885] and Luffa begomovirus (LBgV) (AY309957). $96 \%$ nucleotide identity was reported with ToLCNDV in Raebareli (JX232220), Cotton (EF063145), Chili pepper (DQ116880, HM007113), Pumpkin (AM286434), Luffa (AM292302), Cucumis (KC545812) and ToLCNDV reported from various locations like Siliguri (HQ597032), Lucknow (KC513822), and mild (U15016) and severe (HM159454) ToLCNDV virus in India (Table 1).

The phylogenic analysis grouped BegomoBitterGourd-SL virus with ToLCNDV-BG in a cluster with $97 \%$ identity (Figure 4), showing their close genetic relationship. Further, the Begomo-BitterGourdSL Virus falls into a fairly big cluster with Squash Leaf

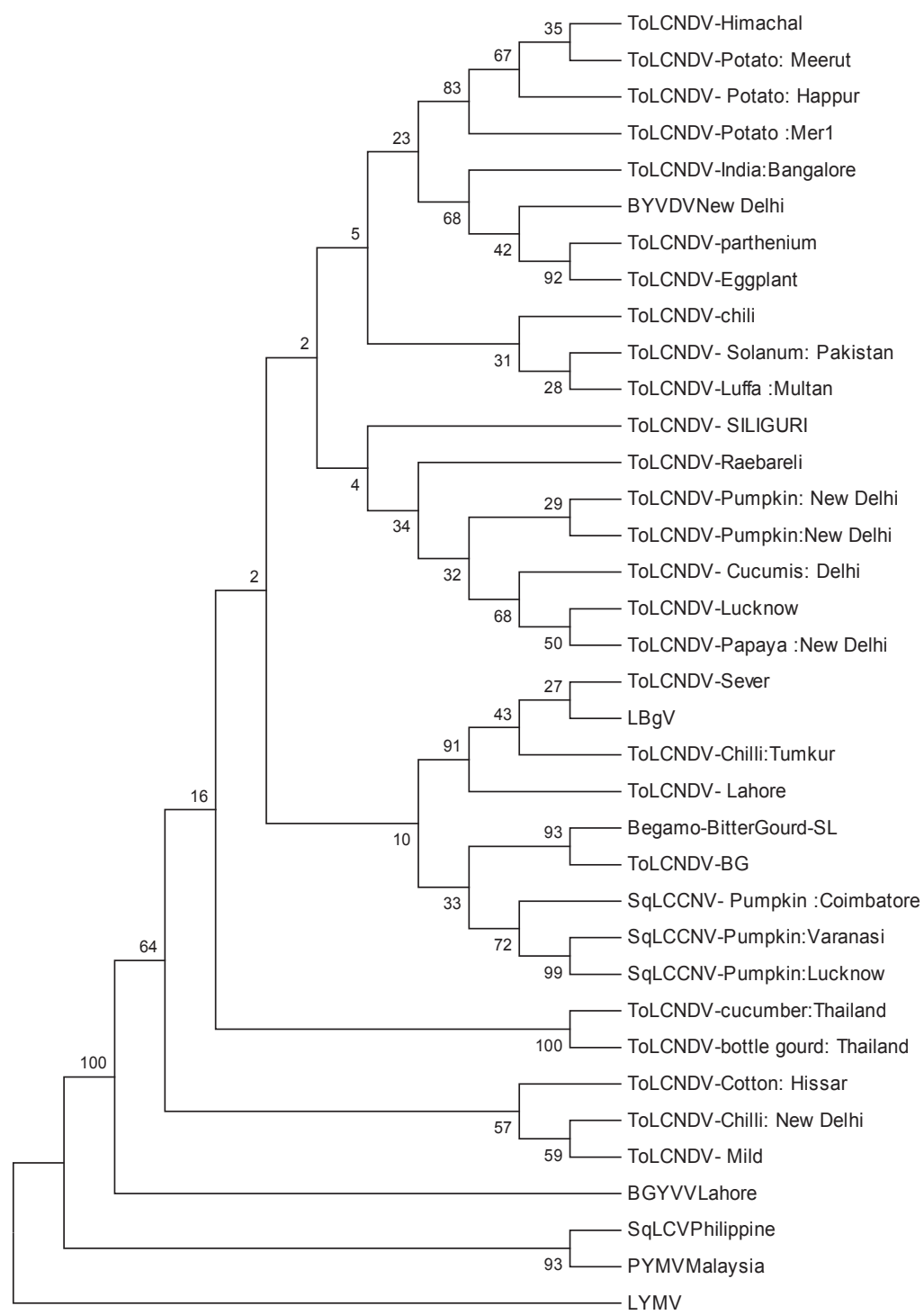

Figure 4: Phylogenic tree constructed using MEGA 4.0 at 1000 bootstrap value showing the relationship of Begomo-Bitter Gourd-SL virus with other begomoviruses 
Curl China Virus (SqLCCNV) from India, ToLCNDV from India and Pakistan, begomo virus from luffa and ToLCNDV from India, showing the identities of $97-$ $95 \%$. ToLCNDV-cucumber, bottle gourd-Thailand and SqLCCNV-Philippine showed a distant relationship than the respective Indian and Pakistan viruses. Pumpkin Yellow Mosaic Virus (PYMV) from Malaysia, Luffa Yellow Mosaic Virus (LYMV) and Bitter gourd Yellow Vain Virus (BGYVV) were distantly related than ToLCNDV.

\section{DISCUSSION}

The PCR detection of begomovirus using degenerate primers confirmed the association of begomoviruses with bitter gourd, ridge gourd, snake gourd, cucumber and pumpkin samples, which showed symptoms of leaf mosaic, upward leaf curling, shortening internodes, stunting, rosetting, puckering, reduced leaf lamina, flattening of tender stem and fruit malformation. This is the first report of the association of begomoviruses with cucurbits in Sri Lanka.

Begomoviruses have been detected in cucurbits using degenerate primers in many other countries in the tropics and subtropics. Roja's degenerate primers have been used to detect begomoviruses associated with infected squash, cucumber and melon showing curling, blistering, yellowing, mottling and fruit deformation in the Palestine West Bank (Ali-Shtayeh et al., 2010). Briddon \& Markham's degenerate primers have been used with pumpkin plants exhibiting leaf curling and yellowing symptoms in Thailand (Ito et al., 2007). The presence of begomovirus in bitter gourd plants showing yellow blotch symptoms in Pakistan has been confirmed by PCR amplification using a degenerate primer pair designed to conserve regions of the coat protein genes (Tahir \& Haider, 2005). The PCR technique allowed rapid, sensitive, and accurate detection of begomoviruses in cucurbit vegetables with minimal sample preparation (Kushwaha et al., 2010).

The variation of symptoms between different varieties of cucurbits indicated mixed infections with different begomoviruses. Mixed infections of three species of begomoviruses, namely, Tomato leaf curl New Delhi virus, Squash leaf curl China virus and Tomato leaf curl Palampur virus has been reported in association with the Yellow vein mosaic disease of pumpkin in the Varanasi region of North India (Jaiswala et al., 2012). The evolution of virus strains through point mutations, recombination and pseudorecombination is a major factor for the emergence, adaptation and spread of new Gemini viral diseases in the world. Most virulent variants have been developed through recombination of viral genomes such as those associated with cassava mosaic, cotton leaf curl, and tomato leaf curl diseases (Varma \& Malathi, 2003).

CP gene is the most conserved viral gene, and the sequencing of this region is recognized as sufficient for the initial identification of begomoviruses (Fauquet \& Stanley, 2003). According to the results of blast analysis, Begomo-Bitter Gourd-SL Virus showed a $97 \%$ identity with ToLCNDV-BG and it was included in the same cluster with ToLCNDV-BG in phylogenetic analysis. It showed a close genetic relationship between BegomoBitter Gourd-SL Virus and ToLCNDV. If the identities of two different sequences are more than $89 \%$, they are considered to be variants of the same virus (Fauquet \& Stanley, 2003) and Begomo-Bitter Gourd-SL Virus can be considered as a variant of ToLCNDV.

ToLCNDV is an economically important pathogen found to be associated with various crop plants in India, Pakistan, Thailand and Bangladesh. It has been reported for the first time in India from tomato and later on from various crops like chili, cucurbits, potato, papaya, bitter gourd and cotton (Dharmendra et al., 2011).

According to the phylogenic tree the Begamo-Bitter Gourd-SL Virus shows a closer relationship with viruses from geographical areas in India and Pakistan located close to Sri Lanka, than with viruses from Thailand, Malaysia and the Philippines. This provides evidence for the possible risk of transboundary movement of the virus through plant materials and insect vectors. Many begomoviruses are considered as important quarantine pests in the world (Hamilton, 2000).

\section{Acknowlegement}

The authors are grateful to all the staff members of the Plant Pathology Division, Horticultural Crop Research and Development Institute, Gannoruwa, Peradeniya for their support in conducting this study.

\section{REFERENCES}

1. Ali-Shtayeh M.S., Jamous R.M., Hussein E. \& Mallah O. (2010). Epidemiological and molecular characterization of the emerging cucurbit-infecting whitefly-transmitted begomoviruses SLCV in production fields in the Palestinian West Bank. Proceedings of the $2^{\text {nd }}$ Conference on Biotechnology Research and Applications in Palestine, pp. $85-86$. 
2. Altschul S.F., Gish W., Miller W., Myers E.W. \& Lipman D.J. (1990). Basic local alignment search tools. Journal of Molecular Biology 215: 403 - 410.

3. Anonymous (2008). Identification of viruses associated with Yellowing syndrome in cucurbitaceous crops in Sri Lanka, pp. 139 - 140. Seasonal Report Yala 2007. Horticultural Crop Research and Development Institute, Sri Lanka.

4. Ariyaratne I., Weerarathne W.A.P.G. \& Ranathunga R.K. R. (2005). Identification of a new mosaic virus disease of snake gourd in Sri Lanka. Annals of the Sri Lanka Department of Agriculture 7: 13 - 21.

5. Brown J.K. \& Bird J. (1992). Whitefly-transmitted Gemini viruses and associated disorders in the Americas and the Caribbean Basin. Plant Disease 76: 220 - 225. DOI: http://dx.doi.org/10.1094/PD-76-0220

6. Deng D., Mlgrath P.F., Robinson D.J. \& Harrison B.D. (1994). Detection and differentiation of whitefly transmitted Gemini viruses in plants with vector insects by the polymerase chain reaction with degenerate primers. Annals of Applied Biology 125: 327 - 336. DOI: http://dx.doi.org/10.1111/j.1744-7348.1994.tb04973.x

7. Dharmendra P., Kashikar A.R. \& Mukherjee S.K. (2011). Molecular characterization and infectivity of a tomato leaf curl New Delhi virus variant associated with newly emerging yellow mosaic disease of egg plant in India. Virology Journal 8: 305.

DOI: http://dx.doi.org/10.1186/1743-422X-8-305

8. Fauquet C.M. \& Stanley J. (2003). Gemini virus classification and nomenclature: progress and problems. Annals of Applied Biology 142: 165 - 189.

DOI: http://dx.doi.org/10.1111/j.1744-7348.2003.tb00241.x

9. Hagen C., Rojas M.R., Sudarshana M.R., Xoconostle B., Natwick E.T., Turini A. \& Gilbertson R.L. (2008). Biology and molecular characterization of cucurbit leaf crumple virus, an emergent cucurbit-infecting begomovirus in the Imperial Valley of California. Plant Disease 92: $781-793$.

DOI: http://dx.doi.org/10.1094/PDIS-92-5-0781

10. Hamilton D. (2000). Solanaceous crop begomoviruses: Additions to EPPO List. European and Mediterranean Plant Protection Organization Report for March 2000. European and Mediterranean Plant Protection Organization, Paris, France.

11. Ito T., Ogawa T., Samretwanich K., Sharma P. \& Ikegami M. (2007). Yellow leaf curl disease of pumpkin in Thailand is associated with Squash leaf curl China virus. New Disease Reporter 16: 28.

12. Jaiswala N., Sarithaa R.K., Dattaa D., Singha M., Dubeyb R.S., Raia A.B. \& Raia M. (2012). Mixed infections of begomoviruses in pumpkins with yellow vein mosaic disease in North India. Archives of Phytopathalogy and
Plant Protection 45: 938 - 941.

DOI: http://dx.doi.org/10.1080/03235408.2011.646670

13. Kushwaha N., Sing A.K., Chattopadyay B. \& Chakraborty S. (2010). Recent advances in geminivirus detection and future perspectives. Plant Protection Science 1: 1 - 18.

14. Lazarowitz S.G. \& Shepherd R.J. (1992). Gemini virus: genome structure and gene function. critical review. Plant Science 4: 327 - 349 .

DOI: http://dx.doi.org/10.1080/07352689209382350

15. Lodhi M.A., Ye G.N., Weeden N.F. \& Reisch B.I. (1994). A simple and efficient method for DNA extraction from grapevine cultivars, Vitis species and Ampelopsis. Plant Molecular Biology Reporter 12(1): 6 - 13.

DOI: http://dx.doi.org/10.1007/BF02668658

16. Ng T.J. (1993). New opportunities in the Cucurbitaceae, pp. 538 - 546. New Crops (eds. J. Janick \& J.E. Simon). Wiley, New York, USA.

17. Ozaslan M., Aytekin T., Bas B., Kilic I.H., Afacan I.D. \& Dag D.S. (2006). Virus diseases of cucurbits in GaziantepTurkey. Plant Pathology Journal 5: $24-27$. DOI: http://dx.doi.org/10.3923/ppj.2006.24.27

18. Pooma W., Gillette W.K., Jeffrey J.L. \& Petty I.T. (1996). Host and viral factors determine the dispensability of coat protein for bipartite Gemini virus systemic movement. Virology 218(1): 264 - 268.

19. Rojas M.R., Gilbertson R.L., Russel D.R. \& Maxwell D.P. (1993). Use of degenerate, primers in the polymerase chain reaction to detect whitefly transmitted Gemini viruses. Plant Disease 77: 340 - 347.

DOI: http://dx.doi.org/10.1094/PD-77-0340

20. Tahir M. \& Haider M.S. (2005). First report of tomato leaf curl New Delhi virus infecting bitter gourd in Pakistan. New Disease Reporter 10: 50.

21. Tamura K., Dudley J., Nei M. \& Kumar S. (2007). MEGA 4:molecular evolutionary genetics analysis (MEGA) software version 4.0. Molecular Biology Evolution 24: $1596-1599$.

DOI: http://dx.doi.org/10.1093/molbev/msm092

22. Varma A. \& Malathi V.G. (2003). Emerging Gemini virus problems: a serious threat to crop production. Annals of Applied Biology 142(2): 145 - 164.

DOI: http://dx.doi.org/10.1111/j.1744-7348.2003.tb00240.x

23. Weerasinghe W.M.S. (2010). Investigation of leaf curl syndrome in bitter gourd (Momordica charantia). B Sc thesis. Faculty of Agriculture, Rajarata University of Sri Lanka.

24. Wickramaarachchi W.A.R.T., Rajapakshe R.G.A.S., Kumarage A.M., Samarawijaya A.P., Bandaranayake E. \& Premarathna P. (2012). Molecular detection of begomovirus associated with Bean yellowing disease in Sri Lanka. Annals of the Sri Lanka Department of Agriculture 14: $221-231$. 